\title{
A Mathematical Model for Investigating the Effect of Reaction Temperature and Hydrogen Amount on the Catalyst Yield during Propylene Polymerization
}

\author{
G. H. Varshouee, ${ }^{a *}$ A. Heydarinasab, ${ }^{a}$ A. Vaziri, and S. M. G. Zarand ${ }^{\mathrm{b}}$ \\ a Department of Petroleum and Chemical Engineering, Science and Research Branch, \\ Islamic Azad University, Tehran, Iran \\ b Polymer Group, Research and Technology, National Petrochemical Company, Tehran, Iran
}

\begin{abstract}
In this study, the effect of reaction temperature and hydrogen amount, as the most effective process variables on the Ziegler-Natta catalysts yield during propylene polymerization, was investigated with the aid of a validated mathematical model. The approach applied in this modelling was the polymer moment balance technique (population balance approach) derived from the statistics expected value. The model was coded in MATLAB ${ }^{\circledR}$ \& Simulink ${ }^{\circledR}$, and then validated by experimental data coming from a laboratory-scale reactor. The main target of this study was to gain considerable insight into Ziegler-Natta catalyst performance against variables change. The model might be applicable for catalyst makers to evaluate and improve their catalysts, and could also be useful for process chemical engineers to easily operate the plant, replace new catalyst, optimise process conditions, generate new formulation for a new grade, and use maximum catalytic potential. Accordingly, the model could be applied in basic and applied research in this field.
\end{abstract}

\section{Keywords}

Catalyst yield, Ziegler-Natta catalysts, reaction temperature, hydrogen, modelling, population balance technique

\section{Introduction}

Polypropylene is one of the most widely used plastics in the portfolio of petrochemical products. Thanks to a low production cost, reduced environmental impact, and wide range of applications in human life, the demand for the polymer is on the rise daily. Today, high-activity supported Ziegler-Natta catalyst is considered as the main catalyst for its commercial production. The main advantage of using a high-activity catalyst is the reduction in operating costs due to the elimination of some useless operating units belonging to the old product technology concerning low-activity catalysts, ${ }^{1}$ as shown in Fig. 1.

Technology improvement depends on the nature, type, and performance of the used catalyst. In other words, so far, the used catalyst has been the driving force in modification and even abolishment of the old technology. Accordingly, it is necessary to gain a considerable insight into Ziegler-Natta catalyst performance. However, findings of this conception highly rely on the performance of the used catalyst during the polymerization, namely, knowing how to change the used catalyst yield during the polymerization by varying of the process variables in a quality and quantity manner. The most important process variables that have significant effect on the catalyst performance are the reaction temperature and hydrogen.

* Corresponding author: Gholam Hossain Varshouee, Phd,

Email: gh.varshouee@yahoo.com

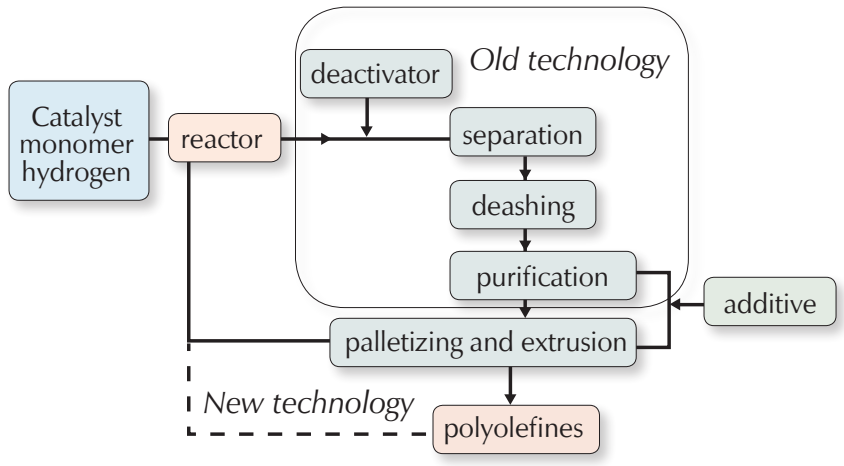

Fig. 1 - Simplified industrial processes for polypropylene production during recent decades ${ }^{1}$

In the catalyst market, there is a wide variety of catalysts that, proposed to commercial plants, each has a unique performance in regard to the complexity of the catalyst kinetics. ${ }^{2}$ Therefore, there is a need for a validated model capable of predicting the performance of the catalyst yield during polymerization.

The main aim of this study was to cover this existing gap with the aid of a validated mathematical model. The significance and outlined aim of this study is summarized as follows:

1. According to the Arrhenius theory, increase in temperature qualitatively increases the rate of polymerization, and should be investigated accurately whether its effect 
is unlimited. On the other hand, increased reaction rate is what quantitatively effects the catalyst yield during the polymerization, and at which temperature the catalyst is expected to perform the best.

2. As we concluded in the previous study, addition of a small amount of hydrogen to the polymerization system dramatically increases the percentage of activated sites from the dormant sites on the catalyst surface. ${ }^{3}$ It should be investigated what effect this event has on the performance of the catalyst yield during the polymerization, and whether this effect is unlimited.

3. Due to the high price of the catalyst, it is necessary to use the maximum potential of the catalyst during the polymerization.

4. The catalyst yield change as an indicator of the rate of polymerization should be under control and compatible with the existing possibilities of the heat removal system in the reactor. This issue is one of the vital criteria for replacing a new catalyst.

In view of the significance of these matters, few researchers have addressed the problems in a comprehensive manner.

Unfortunately, in spite of the long history of using Ziegler-Natta catalyst in polypropylene production, the polymerization system performance still remains a "black box" because the kinetics of polymerization with Ziegler-Natta catalysts are quite complex. ${ }^{2,4}$

Some experimental investigations have been carried out regarding the effect of hydrogen on the kinetics, ${ }^{5-6}$ but their results have been ambiguous and even contradictory. Guastalla and Gianinni concluded that the initial rate and activity of the catalyst increases about 2.5 times when hydrogen exists in the polymerization reactor. ${ }^{7}$ Spitz et al. reported that low hydrogen concentrations in the reactor caused the enhancement of the rate profile, and that higher hydrogen levels lowered activity and increased deactivation of the used catalyst. ${ }^{8}$ Rishina et al. confirmed the previous work, but they pointed out that the role of hydrogen is temporary. ${ }^{9}$ In contrast, Soga and Siona concluded that propylene polymerization rate decreases with the increase in hydrogen partial pressure. ${ }^{10} \mathrm{Kahrman}$ et al. obtained different conclusions that hydrogen had not only an effect upon the polymerization rate for low hydrogen concentrations, but also the rate of polymerization decreases at high hydrogen concentration. ${ }^{11} \mathrm{Al}-$ haj Ali et al. proposed a generalized model for hydrogen response based on the dormant site theory in liquid propylene polymerization. However, his research work was only based on the experimental data without providing a mathematical model, which might be able to predict the polymerization rate profile and the vital indices of the final product properties. ${ }^{12}$ Reginato et al. modelled an industrial-scale loop reactor by using a non-ideal continuous stirred tank model to explain the industrial process, and compared their simulation results with commercial plant data. ${ }^{2}$ The research targets have been defined to predict the macroscopic of the process, dynamics of the plant, advanced control strategies, grade transitions, and average polymer properties. In their paper, despite offering formulas for some important final properties (such as number average molecular weight $\left(M_{n}\right)$, weight average molecular weight $\left(M_{w}\right)$, and polydispersity index $(\bigoplus))$, they did not mention the model validation.

Lastly, in 2018, Varshouee et al. conducted an investigation using a validated kinetics model. They concluded that hydrogen as a transfer agent has a direct effect on the final properties in the form of average molecular weight decrease. On the other hand, hydrogen causes higher activated sites percent on the surface catalyst. ${ }^{3,13}$ The authors also found the best process conditions regarding the deactivation constant, 13,14 average molecular weight and melt flow index of the used catalyst. ${ }^{15}$ They then decided to develop their model in order to cover the aforementioned gaps by proposing a validated mathematical model. This paper is a result of their decision.

To achieve these aims, previously validated model has been developed to become suitable in viewpoint of macro model. The selected modelling technique is the polymer moment balance method (population balance approach) coded in MATLAB ${ }^{\circledR}$ \& Simulink ${ }^{\circledR}$ for slurry polymerization. In order to cover the defined targets completely, this paper has been divided into two parts. The first part deals with the research of the effect of reaction temperature on changing the used catalyst yield during polymerization in absence of hydrogen. The second part focuses on the evaluation of the effect of hydrogen content on varying the used catalyst yield during polymerization and at constant temperature. The implications of this study could be useful for the catalyst makers during evaluation, modification, and improvement of their catalysts that can be considered as a basic research, as well as for process engineers looking to replace new catalyst, increase plant efficiency, and reduce operating costs. Accordingly, this study could be considered in basic and applied research.

\section{Experimental}

The used material, specifications, and the experimental polymerization procedure have already been described in detail in our published work. ${ }^{14}$

\section{Mathematical modelling formulas}

\section{Assumptions:}

The following assumptions were considered in this study: (1) Propylene polymerization reacts in the amorphous phase and its concentration during polypropylene polymerization is constant and equal to the thermodynamic equilibrium condition that obeys that from Sanchez and Lacombe equation (SLE). ${ }^{16}$ (2) The resistance of mass and heat transfer, and the diffusion effect of the reactants are ignored. (3) The reaction is carried out under isothermal and isobar conditions. (4) During the polymerization process, monomer concentration is constant. 


\section{Reactions:}

Regarding the complexity of Ziegler-Natta catalyst kinetics in polypropylene polymerization, several reactions in the polymerization have been proposed in the open literature. ${ }^{2,17}$ The most comprehensive being those of Reginato et al., which were used in this study. ${ }^{2,14}$

The used ODE mass balance equations in this model were as follows: ${ }^{2}$

$$
\begin{aligned}
& \frac{d c_{j, R}}{d t}=\left[\frac{Q_{f} C_{j, f}}{V_{R}}\right]_{\text {feed(input) }}-\left[\frac{Q_{0} C_{j, R}}{V_{R}}\right]_{\text {output }}+R_{j} \\
& \text { where } c_{j, R}=\frac{n(j) / \mathrm{mol}}{V_{\text {total }} / \mathrm{l}} \text { for } j=1,2, \ldots, \mathrm{NC}
\end{aligned}
$$

The variations of the components concentration during polymerization time used in this model were as follows:

$$
C_{j}=C_{\mathrm{H}}, C_{\mathrm{A}}, C_{\mathrm{E}}, C_{\mathrm{Mi}}, C_{\mathrm{B}}, C_{\mathrm{S}}, C_{\mathrm{cat}}, P_{0}^{k}, \mu_{0}^{k}, \mu_{1}^{k}, \lambda_{0}^{k}, \lambda_{1}^{k}, \lambda_{2}^{k}
$$

On the other side, $Q_{f}, Q_{0}$, and $Q_{R}$ are feed volumetric flow rate, reactor-output volumetric flow rate, and volumetric recirculation flow rate, respectively. In the equation, $V_{R}$ and $R_{\mathrm{j}}$ are defined as reactor volume, and $j$ as component reaction rate.

The input and output terms, i.e., $Q_{\mathrm{f}}$ and $Q_{0}$, are eliminated because the model is carried out in a semi-batch reactor and the monomer concentration remains constant during polymerization.

The possible reactions with their rate equations in the polymerization reactor, which should be considered in this study, are listed in Table 1, where $k$ is the site number of the catalyst.

The moment equations, which derived from population balance as the approach of this study, are summarized in Table 2.

Table 1 - Considered probable reactions and their rate equations in this study ${ }^{2,14}$

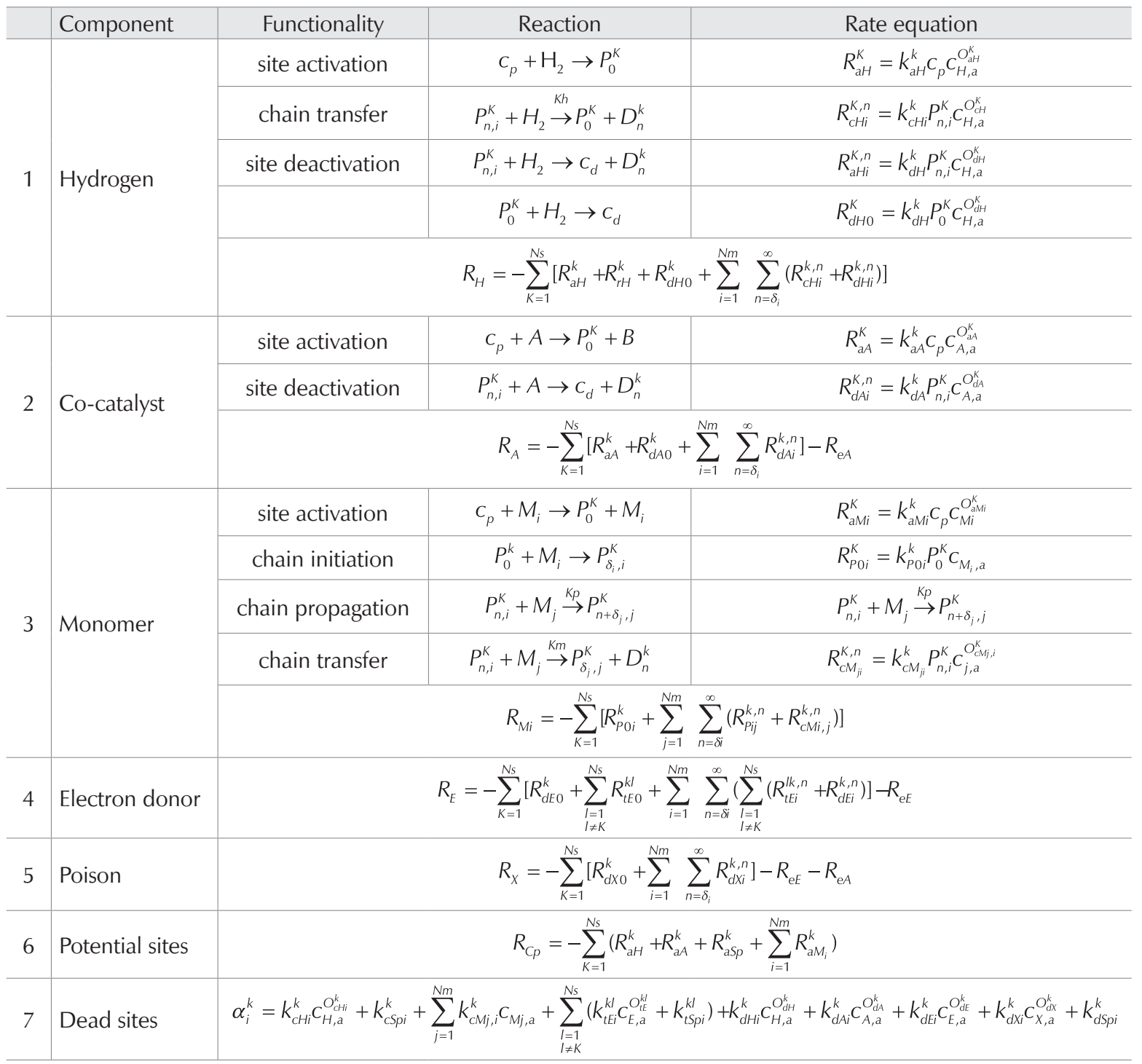


Table 2 - Moment equations used in this model 2,14

\begin{tabular}{|c|c|}
\hline \multicolumn{2}{|r|}{ Moment equations } \\
\hline Live polymer & $R_{P_{n, i}^{k}}=\delta\left(n-\delta_{i}\right)\left[R_{P 0 i}^{k}+\sum_{j=1}^{N m} \sum_{m=\delta i}^{\infty} R_{c M i, j}^{k, m}\right]+\sum_{j=1}^{N m} k_{p i j}^{k} C_{M i, a} P_{n-\delta_{i, j}}^{k}-\sum_{j=1}^{N m} k_{p i j}^{k} C_{M j, a} P_{n, i}^{k}-\alpha_{i}^{k} P_{n, i}^{k}$ \\
\hline Dead polymer & 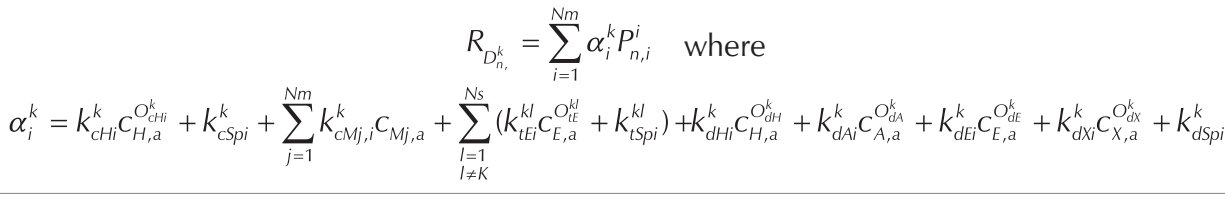 \\
\hline Live moment & $\mu_{\delta_{i}, i}^{k}=\sum_{n=1}^{\infty} n^{\delta_{i}} P_{n, i}^{k}$ \\
\hline Bulk moment & $\lambda_{\delta_{i}}^{k}=\sum_{n=\delta_{i}}^{\infty}\left(\sum_{i=1}^{N m} P_{n, i}^{k}+D_{n}^{k}\right)$ \\
\hline $\begin{array}{l}\text { Zero-order; live } \\
\text { polymer moments }\end{array}$ & $R_{\mu_{0, i}^{k}}=R_{P 0 i}^{k}+\sum_{j=1}^{N m} k_{c M_{i, j}}^{k} C_{M i, a} \mu_{0, j}^{k}-\alpha_{i}^{k} \mu_{0, j}^{k}+\sum_{j=1}^{N m}\left[k_{p i j}^{k} C_{M i, a} \mu_{0, j}^{k}-k_{p j i}^{k} C_{M j, a} \mu_{0, i}^{k}\right]$ \\
\hline $\begin{array}{l}\text { First-order; live } \\
\text { polymer moments }\end{array}$ & $R_{\mu_{0,}^{k}}=\sum_{i=1}^{N m} \delta(i-I)\left[R_{p 0 i}^{k}+\sum_{j=1}^{N m} k_{c M_{i}, j}^{k} C_{M i, a} \mu_{0, J}^{k}\right]-\sum_{i=1}^{N m} \alpha_{i}^{k} \mu_{\delta_{l,}, i}^{k}+\sum_{i=1}^{N m} \sum_{j=1}^{N m} k_{p i j}^{k} C_{M i, a} \delta(i-1) \mu_{0, J}^{k}$ \\
\hline $\begin{array}{l}\text { Zero-order; bulk } \\
\text { polymer moments }\end{array}$ & $R_{\lambda_{0}^{k}}=\sum_{i=1}^{N m}\left[R_{P 0 i}^{k}+\sum_{j=1}^{N m} k_{c M_{i}, j}^{k} C_{M i, a} \mu_{0, j}^{k}\right]$ \\
\hline $\begin{array}{l}\text { First-order; bulk } \\
\text { polymer moment }\end{array}$ & $R_{\lambda_{\delta, ~}^{k}}=\sum_{i=1}^{N m} \delta(i-l)\left[R_{P 0 i}^{k}+\sum_{j=1}^{N m} k_{c M_{i, j}}^{k} C_{M i, a} \mu_{0, J}^{k}\right]+\sum_{i=1}^{N m} \sum_{j=1}^{N m} \delta(i-1) k_{p i j}^{k} C_{M i, a} \mu_{0, J}^{k}$ \\
\hline $\begin{array}{l}\text { Second-order; bulk } \\
\text { polymer moment }\end{array}$ & $R_{\lambda_{2}}=\sum_{k=1}^{N s} \sum_{j=1}^{N m}\left[R_{P 0 i}^{k}+\sum_{i=1}^{N m} k_{c M j, i}^{k} C_{M j, a} \mu_{0, i}^{k}\right]+\sum_{k=1}^{N s} \sum_{i=1}^{N m} \sum_{j=1}^{N m} k_{p j i}^{k} C_{M j, a}\left(\mu_{0, i}^{k}+2 \mu_{1, i}^{k}\right)$ \\
\hline
\end{tabular}

Pater et al. and some other researchers showed that the rate of polymerization at isothermal conditions could be described as a first-order process in monomer concentration and the deactivation of the catalyst as a first-order process in the number of active sites. The following equations were used: $5,6,12$

$$
\begin{gathered}
R_{\mathrm{p}}=K_{\mathrm{p}} C_{\mathrm{m}} \mathrm{C}=R_{\mathrm{p} 0} \cdot \exp \left(-k_{\mathrm{d}} \cdot t\right)=R_{\mathrm{p} 0} \cdot \exp \left(-\frac{E_{\mathrm{a}}}{R T}\right) \\
\frac{d c}{d t}=-K_{\mathrm{d}} C, \text { where } \ldots k_{\mathrm{d}}=k_{\mathrm{d} 0} \cdot \exp \left(\frac{-E_{\mathrm{a}, \mathrm{d}}}{R T}\right)
\end{gathered}
$$

where $R_{\mathrm{p} 0}$ is the initial reaction rate, $K_{\mathrm{d}}$ is the deactivation constant, $E_{\mathrm{a}, \mathrm{d}}$ is the activation energy for the lumped deactivation reaction, $c$ is activated site of the catalyst during polymerization, $t$ is the time, $T$ is the temperature, and $K_{\mathrm{P}}$ is the rate constant of the propagation reaction.

By plotting the natural logarithm of the reaction rate vs. polymerization time, a linear fit can be made where $K_{\mathrm{d}}$ is the slope of the fit line, and $R_{\mathrm{p} 0}$ is the intercept of the line.

Considering that the rate of polymerization has a dependency on temperature, by having $R_{\mathrm{p} 0}$ at different temperatures and by using Arrhenius Eq. 2, the activation energy of any type of catalyst is easily predictable.

In this study, it is supposed that the catalyst has mono-site, and therefore, $k$ is equal to one. Here, $C_{\mathrm{H}}, C_{\mathrm{A}}, C_{\mathrm{E}}, C_{\mathrm{Mi}}, C_{\mathrm{B}}, C_{\mathrm{S}}$,
$C_{\text {cat }}$ and $P_{0}$ are the concentration of hydrogen, co-catalyst (aluminium alkyl), electron donor, monomer, poison, site transfer, catalyst, and potential site in the polymerization, respectively. The component rate equations and moment equations that have been used in the model are listed in Table 2.

The polymerization yield can be calculated by integrating the rate:

$$
Y_{\text {calc }}=\int_{0}^{t} R_{\mathrm{p}} \cdot \mathrm{d} t
$$

The amount of $Y_{\text {calc }}$ is exactly equal to the area under the profile curve.

In this polymerization, hydrogen as a transfer agent increases the rate of the polymerization and the percent of activated sites named as $f_{\mathrm{H} 2}$ being on the surface of the used catalyst according to the dormant site theory. ${ }^{3}$ By inserting $f_{\mathrm{H} 2}$ into Eq. 1, the following equation is derived that could be able to predict the effect of hydrogen on the polymerization rate.

$$
R_{\mathrm{p}}=K_{\mathrm{p}} \cdot C_{\max } \cdot C_{\mathrm{m}} \cdot f_{\mathrm{H}_{2}}
$$

where $f_{\mathrm{H} 2}$ represents the fraction of active sites in the system. In the absence of hydrogen $x=0, f_{\mathrm{H} 2}$ has the minimum amount. It means active sites of catalyst are at a minimum level in the polymerization system. Consequently, if 
$f_{\mathrm{H} 2, \max }=1$, namely, $100 \%$ of the catalyst sites in reaction are active.

\section{Modelling algorithm}

Fig. 2(A) shows the designed algorithm for coding the mathematical model, which runs in MATLAB ${ }^{\circledR}$ \& Simulink ${ }^{\circledR}$ software. It is divided into two parts - the first part belongs to main-program named "Runsim" and the other is its subroutine program named "Function File".

This algorithm is developed in our previous work ${ }^{14}$ according to existing gaps that are defined in this study.

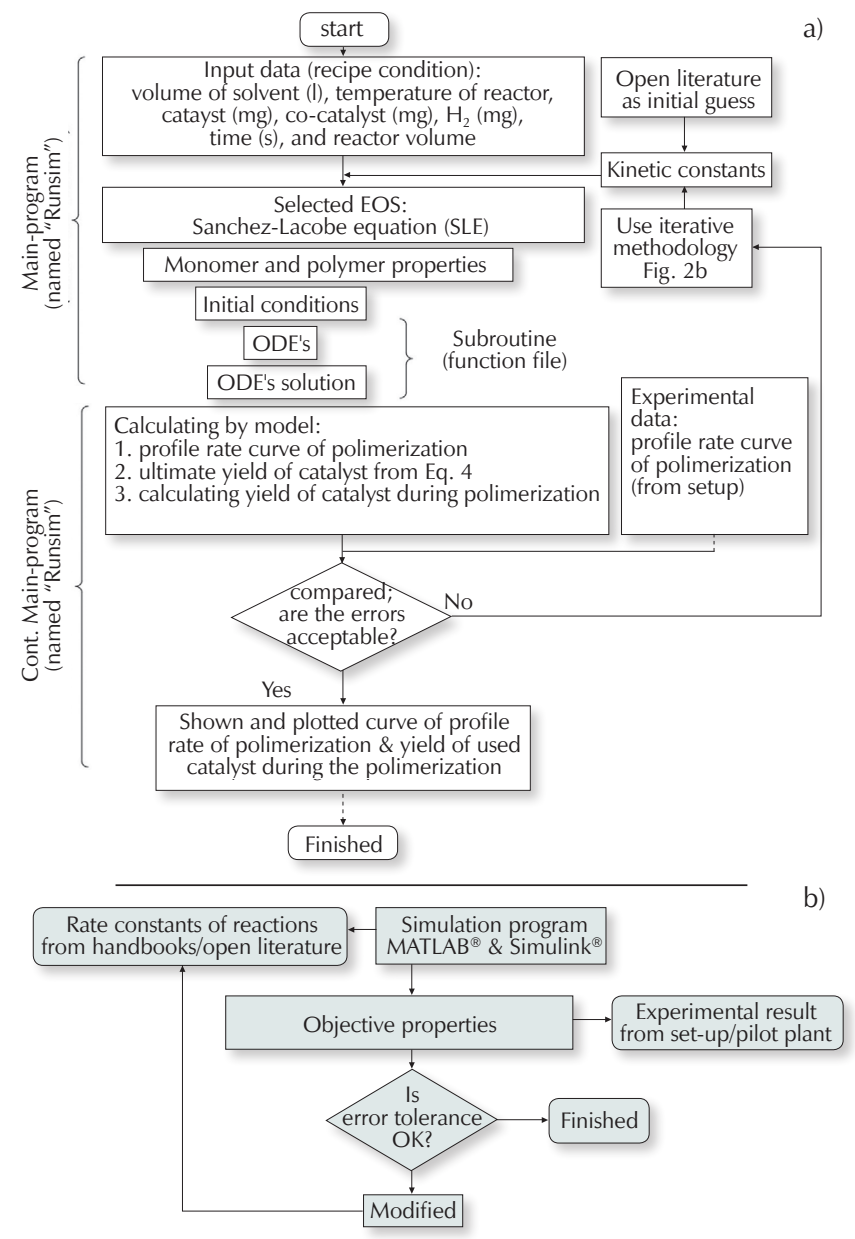

Fig. 2 - (a) Algorithm developed for coding in this study; (b) Iterative method used for adjusting kinetic parameters

We propose a new approach, i.e., iterative method algorithm, using consistency property of the ordinary differential equation (ODE). As we know, in numerical calculations, the ODEs have the consistency property, and by using this property, the iterative method should be able to solve ODEs exactly by only one rational initial guess. This method is much easier and more reliable than conventional methods, i.e., using them directly from the open literature or estimating by trial and error. ${ }^{2}$ By using this property, we outlined a novel algorithm for obtaining kinetic constants in this model, as shown in Fig. 2 b.

To use the iterative method algorithm, only the initial guess of kinetic constants should be estimated by referring to the open literature. Afterwards, the kinetic constants are adjusted for the catalyst used by the algorithm.

In this study, the initial guess of kinetic constants was estimated and applied to the model from the open literature. ${ }^{2,17}$ Then, the constants were exactly adjusted and determined in accordance with the catalyst used in the set-up (experimental data) by the algorithm proposed in Fig. 2 b.

\section{Results and discussion}

Firstly, in order to rely on the performance and results of the model proposed in this study, it is necessary to prove that the model is validated properly. In modelling, when the calculated amount of activation energy from the model is equal or very close to the amount from experimental works and in accordance with other researchers' results, it means that the model is validated properly. Therefore, that activation energy is an inherent property of the reaction, and it is also independent of any process variable. Accordingly, this subject could be considered as one of the important criteria that shows whether the model is properly validated. Two very important facts should be considered about the activation energy of Z. N. catalyst. Firstly, it is independent of the hydrogen concentration. ${ }^{12}$ Secondly, this inherent property of the reaction belongs to the used catalyst type and thus can be expected to differ in its amount from one type to another. Table 3 reveals that the provided model in this study is validated properly.

Table 3 - Reported activation energies $\left(E_{\mathrm{a}}\right)$ in propylene polymerization ${ }^{13}$

\begin{tabular}{l|l|c|c}
\hline Worker & Catalyst system & Phase & $E_{\mathrm{a}} / \mathrm{KJ} \mathrm{mol}^{-1}$ \\
\hline Yuan et al. ${ }^{17}$ & $\delta$-TiCl $.1 / 3 \mathrm{AlCl}_{3} / \mathrm{DEAC}$ & slurry & 53.9 \\
\hline Soares et al. ${ }^{19}$ & $\mathrm{TiCl}_{3} / \mathrm{DEAC}$ & slurry & 57.7 \\
\hline $\begin{array}{l}\text { This work; } \\
\text { experimental. } \\
\text { (ave) }\end{array}$ & $\begin{array}{l}\mathrm{MgCl}_{2} / \mathrm{TiCl}_{4} / \text { phthalate/ } \\
\text { silane/TEA }\end{array}$ & slurry & 55.53 \\
\hline $\begin{array}{l}\text { This work; } \\
\text { model (ave) }\end{array}$ & $\begin{array}{l}\mathrm{MgCl}_{2} / \mathrm{TiCl}_{4} / \text { phthalate/ } \\
\text { silane/TEA }\end{array}$ & slurry & 53.05 \\
\hline
\end{tabular}

Table 4 represents the comparison of the model output and experimental results at different conditions or recipe of the polymerization, and shows that the model has been properly validated due to the model outputs being in accordance with the experimental results. The acceptable error of these comparisons could be considered as a second reason for being the validated model. The third reason is 
Table 4 - Comparison of the model output and experimental results at different conditions ${ }^{2,13}$

\begin{tabular}{|c|c|c|c|c|c|c|c|}
\hline \multicolumn{5}{|c|}{ Recipe or experimental conditions } & \multicolumn{3}{|c|}{ Results (experimental/model) } \\
\hline $\begin{array}{l}\text { Run No. } \\
\text { (1) }\end{array}$ & $\begin{array}{c}T /{ }^{\circ} \mathrm{C} \\
(2)\end{array}$ & $\begin{array}{c}m\left(\mathrm{H}_{2}\right) / m g \\
(3)\end{array}$ & $\begin{array}{c}m \text { (catalyst) } / \mathrm{mg} \\
\text { (4) }\end{array}$ & (5) & $\begin{array}{l}Y / g \\
(6)\end{array}$ & $\begin{array}{l}R_{\mathrm{p} 0} \\
(7)\end{array}$ & $\begin{array}{c}K_{d}(1 / h) \\
(8)\end{array}$ \\
\hline \multirow{3}{*}{1} & \multirow{3}{*}{65} & \multirow{3}{*}{0} & \multirow{3}{*}{20} & E. R. ${ }^{1}$ & 63.29 & 5.01 & 1.42 \\
\hline & & & & M. R. ${ }^{2}$ & 65.13 & 5.19 & 1.42 \\
\hline & & & & error \% & 3 & 3 & 1 \\
\hline \multirow{3}{*}{2} & \multirow{3}{*}{70} & \multirow{3}{*}{0} & \multirow{3}{*}{20} & E. R. ${ }^{1}$ & 72.66 & 6.5 & 1.95 \\
\hline & & & & M. R. ${ }^{2}$ & 76.4 & 7.46 & 1.98 \\
\hline & & & & error \% & 5 & 13 & 2 \\
\hline \multirow{3}{*}{3} & \multirow{3}{*}{75} & \multirow{3}{*}{0} & \multirow{3}{*}{20} & E. R. ${ }^{1}$ & 63.07 & 8.85 & 2.04 \\
\hline & & & & M. R. ${ }^{2}$ & 67.25 & 8.92 & 2.13 \\
\hline & & & & error \% & 6 & 1 & 4 \\
\hline \multirow{3}{*}{4} & \multirow{3}{*}{70} & \multirow{3}{*}{$18^{3}$} & \multirow{3}{*}{10} & E. R. ${ }^{1}$ & 81.33 & 11.24 & 2.27 \\
\hline & & & & M. R. ${ }^{2}$ & 88.4 & 11.43 & 2.3 \\
\hline & & & & error \% & 8 & 2 & 1 \\
\hline \multirow{3}{*}{5} & \multirow{3}{*}{70} & \multirow{3}{*}{$27^{4}$} & \multirow{3}{*}{10} & E. R. ${ }^{1}$ & 74.61 & 11.02 & 2.05 \\
\hline & & & & M. R. ${ }^{2}$ & 76.81 & 11.2 & 2.15 \\
\hline & & & & error \% & 3 & 2 & 5 \\
\hline \multicolumn{8}{|c|}{$x$ - hydrogen molar ratio - calculated by Aspen Software, polymer software based on SLE (SOE) } \\
\hline \multicolumn{4}{|c|}{${ }^{1}$ Experimental result } & \multicolumn{4}{|c|}{${ }^{3} 18 \mathrm{mg} \mathrm{H}_{2}$ is equivalent to 0.00466 molar ratio $x$. } \\
\hline \multicolumn{4}{|c|}{${ }^{2}$ Model result } & \multicolumn{4}{|c|}{${ }^{4} 27 \mathrm{mg} \mathrm{H}_{2}$ is equivalent to 0.00703 molar ratio $x$. } \\
\hline
\end{tabular}

that the trends of the profile polymerization rate from the model and from the experimental works have remarkable conformity, as shown in Figs. 3(A) and 3(B). ${ }^{14}$

The main conclusion that can be attained from these arguments is that the model is properly validated. That means that the selected approach and the designed algorithms (Fig. 2) in this study are appropriate; i.e., it is able to tune the kinetics parameters in a proper way. Therefore, the model's results can be worthy and reliable for achieving the aim of this study.

With relevance to the model that has been directly derived from kinetic equations and its validity has been proven; consequently, it is developed with the aforementioned objectives and is perfectly reliable.

Our previous model was able to calculate the ultimate catalyst yield and predict the profile rate of the polymerization, but it was not able to evaluate the aim of this study, i.e., the effect of process variables such as reaction temperature and hydrogen content on the catalyst yield during the polymerization.

As outlined in the introduction, in order to cover the defined targets, this paper has been divided into two parts. The aim of the first part was to study the effect of changing reaction temperature on the catalyst yield during the polymerization, and the aim of the second part was to evaluate the effect of hydrogen amounts on it as well.
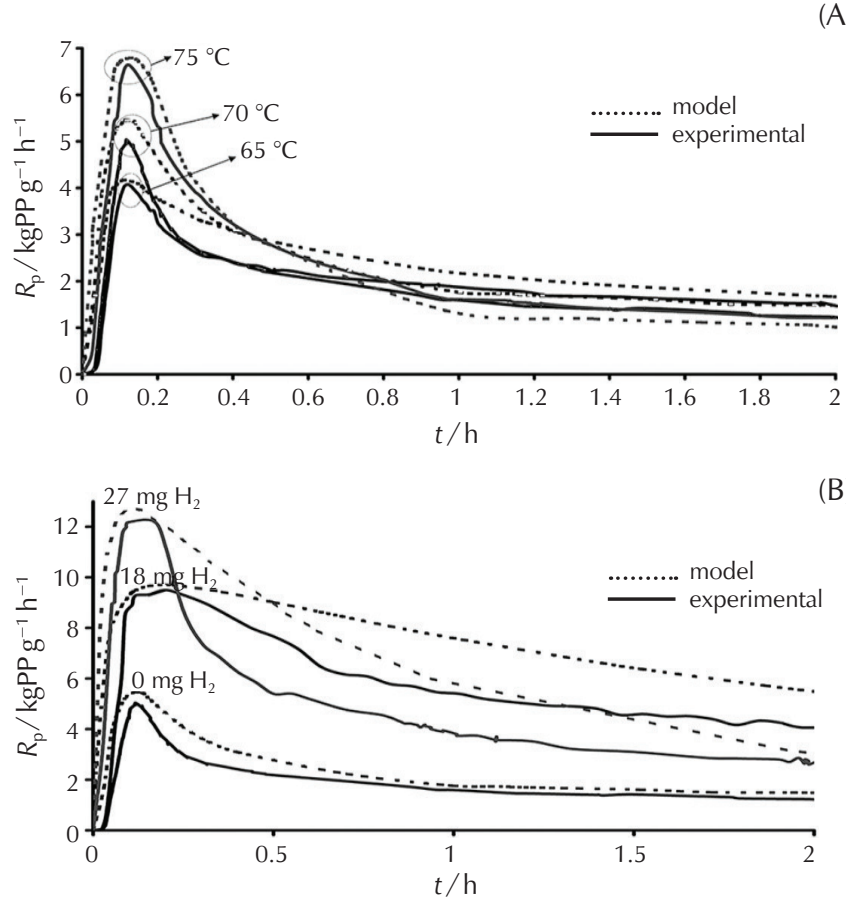

Fig. 3 -Comparison of the experimental and model profile rates $(\mathrm{A})$ in the absence of hydrogen at different temperatures; (B) at $70{ }^{\circ} \mathrm{C}$ and different hydrogen amounts. 


\section{First part of the study}

It is important to reiterate that the obtained conclusions belong to the previous works because this work was developed from the earlier model with the aim of covering the existing gaps in this study.

Fig. 4(A) reveals that catalyst yield at $70{ }^{\circ} \mathrm{C}$ is at maximum in the absence of hydrogen. Temperature increase, according to Arrhenius equation, i.e., Eq. 3, causes the increase in deactivation constant $\left(K_{\mathrm{d}}\right)$, which is an undesirable event, because the age of the used catalyst would be reduced, i.e., $K_{d}$ for Runs 1, 2, and 3 as shown in col. (8) of Table 4. At higher temperatures $>70{ }^{\circ} \mathrm{C}, K_{\mathrm{d}}$ is increased, and this increase decreases the yield of polymerization. In other words, increased reaction temperature $>70{ }^{\circ} \mathrm{C}$ not only has a useful effect, but also has a harmful effect on the used catalyst yield. Consequently, temperature increase for raising the catalyst yield is not unlimited. This event could be attributed to over reduction of the catalyst sites or alkylation reaction with the Lewis base..$^{20,21}$

The developed model in this study is able to calculate and plot at any time during the polymerization. Fig. 4(B) illus- trates the cumulative catalyst yield during the polymerization time, i.e., two hours at different temperatures in the absence of hydrogen.

The figure shows that the performance of the developed model is in accordance with the experimental result in an acceptable margin of error. It can be concluded from the figure that, during the polymerization, the cumulative catalyst yield obeys that from the quadratic equation as its model. Fig. 4(B) implies that the temperature increase above $70{ }^{\circ} \mathrm{C}$ not only causes the catalyst yield increase, but also leads to the reduction of the useful life of the catalyst, which is an undesired event.

For the best reaction temperature in this study, i.e., Run 2 at the reaction temperature of $70{ }^{\circ} \mathrm{C},{ }^{14}$ the variations of the cumulative catalyst yield during the polymerization time with its model are demonstrated in Fig. 5(A). For the rest of the runs, the models are listed in Table 5, column 7. These models could be useful for process engineers working in a commercial plant for tuning and optimisation of the residence time of the catalyst in a continuous reactor according to the desired purpose.
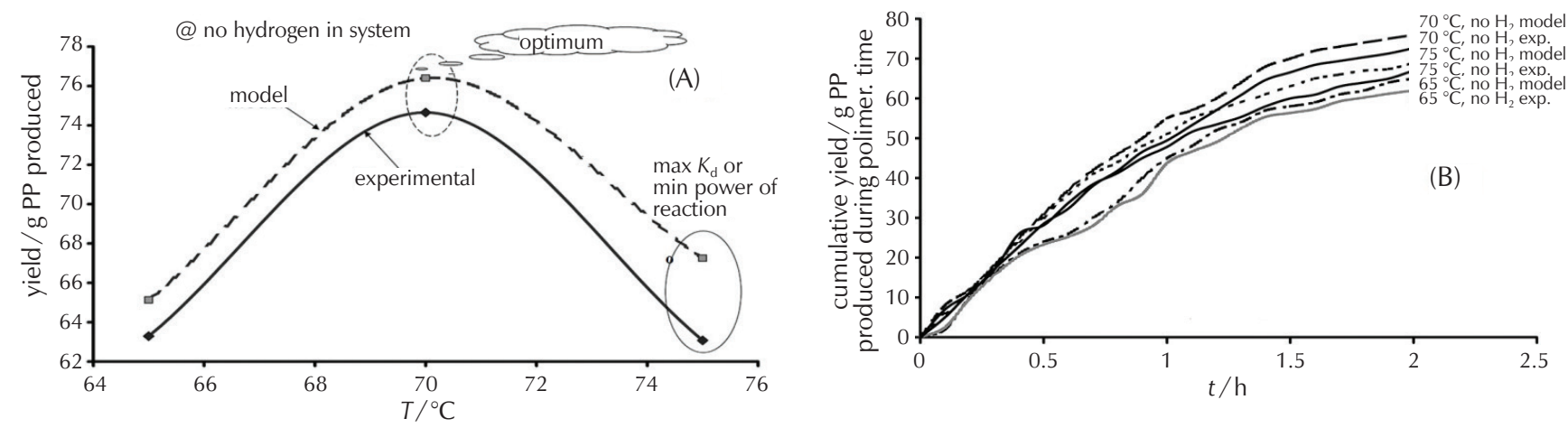

Fig. 4 - (A) Comparison of the experimental data and model prediction of the yield (gr PP) in the absence of hydrogen with variations in temperature (Runs 1, 2, 3); (B) Comparison of the cumulative catalyst yield during the polymerization in the absence of hydrogen with variations in temperature (Runs 1, 2, 3)
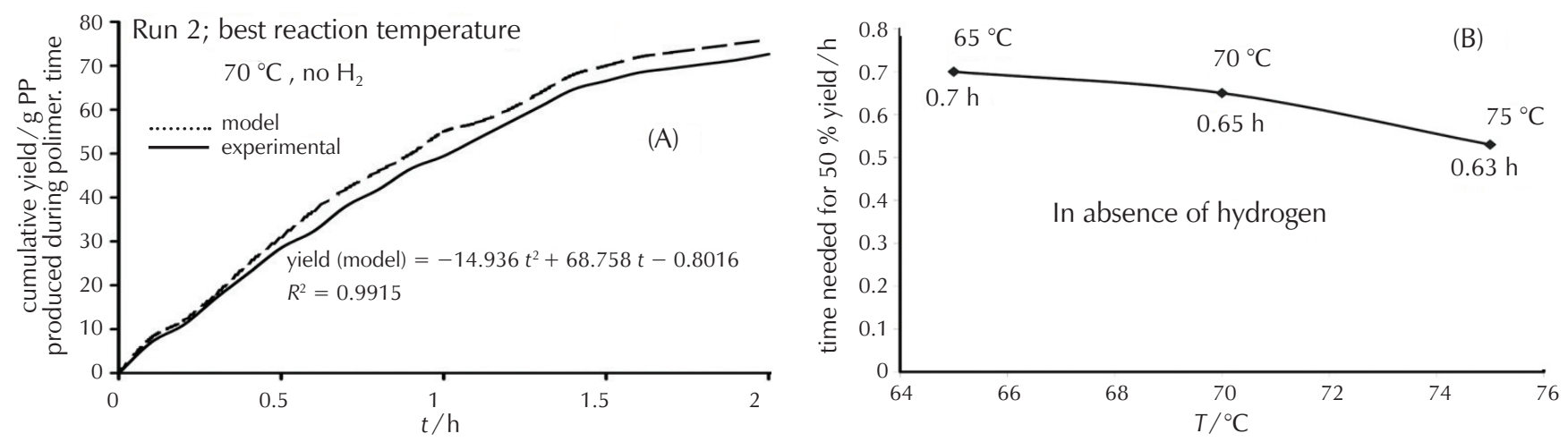

Fig. 5 - (A) Comparison of the experimental data and model prediction of the yield (gr PP) during the polymerization at the best reaction temperature in the absence of hydrogen (Run 2); (B) Variations in the time needed for $50 \%$ of catalyst yield in the absence of hydrogen with different reaction temperatures (Runs 1, 2, 3) 
The model shows that $0.7 \mathrm{~h}$ after the beginning of polymerization, $50 \%$ of the used catalyst yield is formed and obtained. Increased reaction temperature causes the reduction in the time needed for obtaining $50 \%$ of the catalyst yield, Fig. 5(B)

The graphical image of $50 \%$ of the catalyst yield represents the area underneath the polymerization profile rate relating to areas I and II that are indicators of the effective residence time of the used catalyst, as detailed in Fig. 6 . In basic research, it could be a suitable criterion for comparing the performance of different types of catalysts.

The polymerization time is listed in Table 5. The catalyst yield and the percent of production related to each area of each run is shown in Fig. 6.

\section{Second part of the study}

As mentioned earlier, the defined aim of this part was to evaluate the effect of hydrogen amounts on the catalyst yield during the polymerization. As already reported, hydrogen as a transfer agent in this polymerization increases the rate of polymerization and percent of the activated sites named as $f_{\mathrm{H} 2}$ being on the surface of the used catalyst

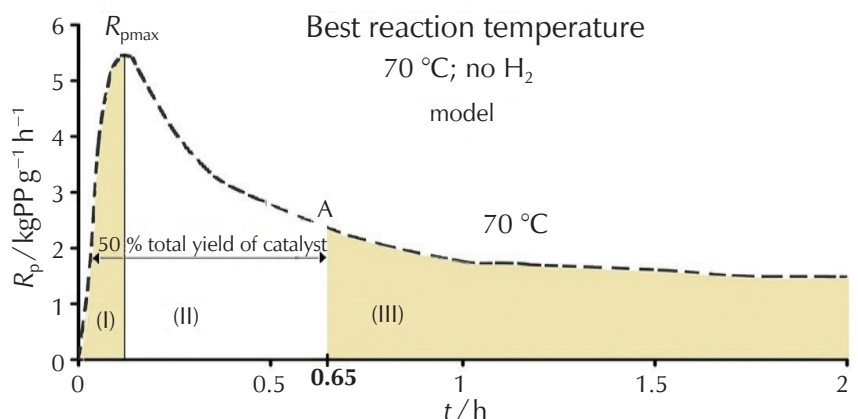

Fig. 6 - Graphical determination of the time needed for obtaining $50 \%$ of the catalyst yield using the polymerization profile rate at the best reaction temperature (Run 2)

according to the dormant site theory. ${ }^{3}$ This increase in the percent of activated sites does not mean that it causes a rise in the catalyst yield absolutely, because part of these activated sites react with hydrogen and are killed off. On the other hand, the yield of the defined catalyst is based on the polymer which is produced.

Therefore, $f_{\mathrm{H} 2}$ is one of the key parameters in polymerization rate equation, i.e., Eq. 5, which should be consid-
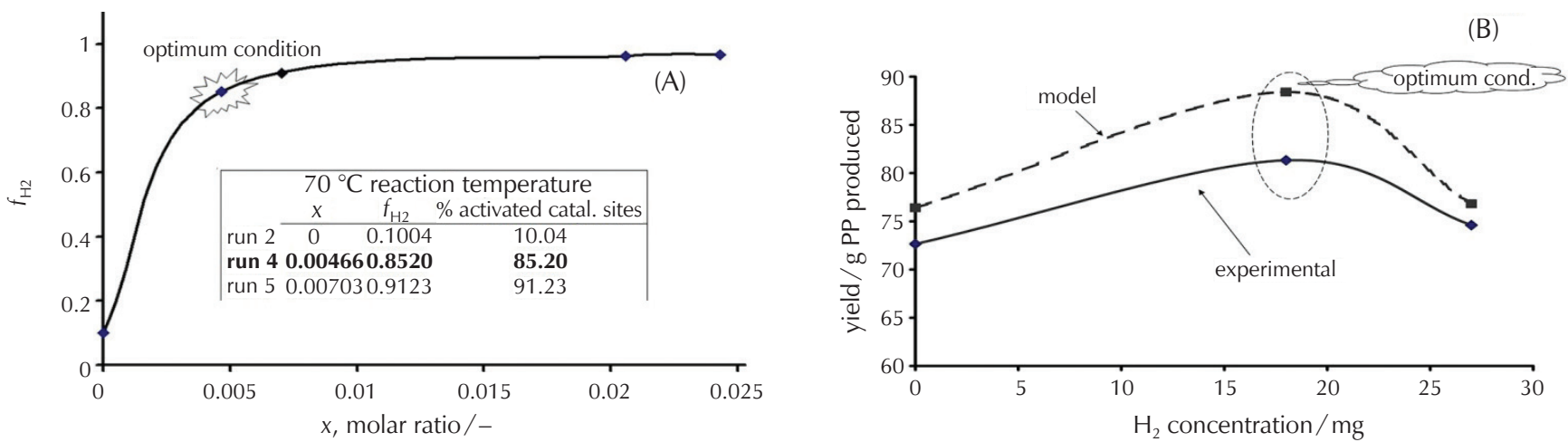

Fig. 7 - (A) Variations of the fraction of active sites $\left(f_{\mathrm{H} 2}\right)$ by changing the hydrogen amount; (B) Comparison of the experimental data and model prediction of the yield (g PP) at optimum temperature $\left(70{ }^{\circ} \mathrm{C}\right.$ ) with variations of the hydrogen amounts (Runs 2 , $4,5)$.
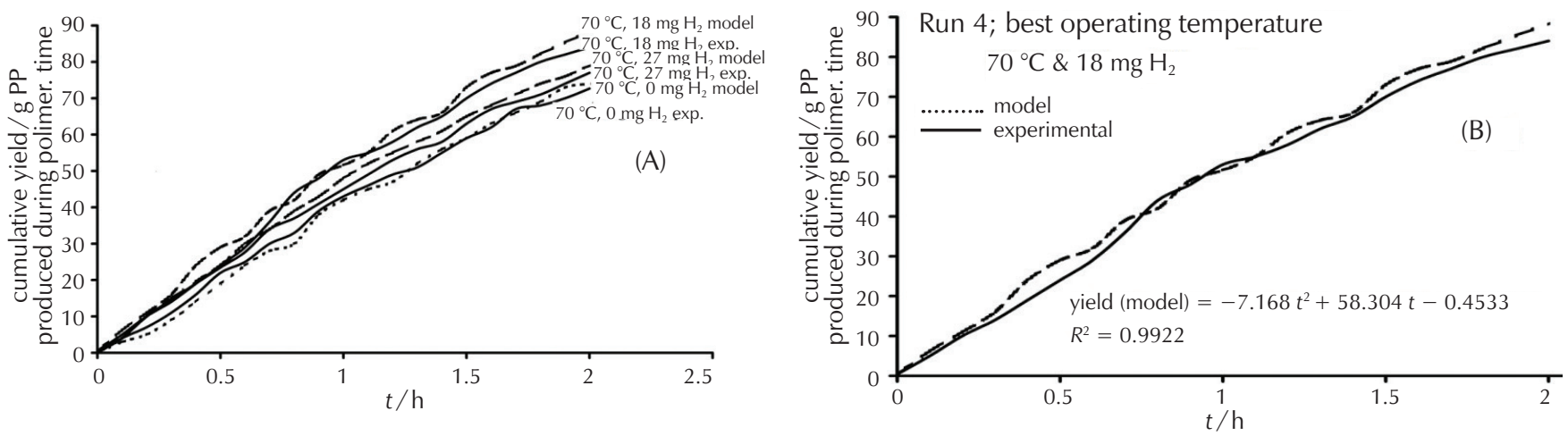

Fig. 8 - (A) Comparison of the cumulative catalyst yield during the polymerization in the presence of different hydrogen amounts at the best reaction temperature (Runs 2, 4 and 5); (B) Comparison of experimental data and model prediction of the yield (g PP) during polymerization in the best process conditions (Run 4) 
Table 5 - Specification of each zone of the polymerization rate for each run as shown in Figs. 6 \&10

\begin{tabular}{|c|c|c|c|c|c|c|c|}
\hline & $\begin{array}{l}\text { Area } \\
(1)\end{array}$ & $\begin{array}{l}f_{\mathrm{H} 2} \\
(2)\end{array}$ & $\begin{array}{l}\text { Polym. time } / \mathrm{h} \\
\text { (3) }\end{array}$ & $\begin{array}{l}\text { Yield / } \\
\mathrm{Kg} / \mathrm{g} \text { cat } \\
(4)\end{array}$ & $\begin{array}{l}\% \text { Total } \\
\text { production } \\
\text { (5) }\end{array}$ & $\begin{array}{l}\text { Time needed } \\
\text { for } 50 \% \text { of } \\
\text { production } / \mathrm{h} \\
\text { (6) }\end{array}$ & $\begin{array}{c}\text { Model Y vs. } t / \mathrm{h} \\
\text { (7) }\end{array}$ \\
\hline \multirow{4}{*}{ Run 1} & I & 0.1004 & 0.11 & 3.57 & 5.80 & \multirow{4}{*}{0.7} & \multirow{4}{*}{$\begin{array}{c}\text { Yield (model) }= \\
=-12.295 \cdot t^{2}+57.75 \cdot t-1.3023 \\
R^{2}=0.9918\end{array}$} \\
\hline & II(A) & 0.1004 & 0.5 & 20.53 & 33.35 & & \\
\hline & III & 0.1004 & 2 & 37.46 & 60.85 & & \\
\hline & total & 0.1004 & & 61.56 & 100.00 & & \\
\hline \multirow{4}{*}{ Run 2} & I & 0.1004 & 0.109 & 5.33 & 6.97 & \multirow{4}{*}{0.65} & \multirow{4}{*}{$\begin{array}{c}\text { Yield }(\text { model })= \\
=-14.936 \cdot t^{2}+68.758 \cdot t-0.8016 \\
R^{2}=0.9915\end{array}$} \\
\hline & II(A) & 0.1004 & 0.5 & 27.53 & 36.03 & & \\
\hline & III & 0.1004 & 2 & 43.55 & 57.00 & & \\
\hline & total & 0.1004 & & 76.40 & 100.00 & & \\
\hline \multirow{4}{*}{ Run 3} & I & 0.1004 & 0.08 & 4.66 & 6.25 & \multirow{4}{*}{0.53} & \multirow{4}{*}{$\begin{array}{c}\text { Yield }(\text { model })= \\
=-20.998 \cdot t^{2}+75.91 \cdot t-0.5705 \\
R^{2}=0.9887\end{array}$} \\
\hline & II(A) & 0.1004 & 0.5 & 34.97 & 46.88 & & \\
\hline & III & 0.1004 & 2 & 34.97 & 46.88 & & \\
\hline & total & 0.1004 & & 74.60 & 100.00 & & \\
\hline \multirow{4}{*}{ Run 4} & 1 & 0.852 & 0.111 & 7.43 & 8.40 & \multirow{4}{*}{0.82} & \multirow{4}{*}{$\begin{array}{c}\text { Yield }(\text { model })= \\
=-7.168 \cdot t^{2}+58.304 \cdot t+0.4533 \\
R^{2}=0.9922\end{array}$} \\
\hline & II(A) & 0.852 & 0.6 & 25.28 & 28.60 & & \\
\hline & III & 0.852 & 2 & 55.69 & 63.00 & & \\
\hline & total & 0.852 & & 88.40 & 100.00 & & \\
\hline \multirow{4}{*}{ Run 5} & I & 0.9123 & 0.101 & 5.82 & 7.58 & \multirow{4}{*}{0.81} & \multirow{4}{*}{$\begin{array}{c}\text { Yield (model) }= \\
=-6.2387 \cdot t^{2}+50.71 \cdot t+0.3372 \\
R^{2}=0.9909\end{array}$} \\
\hline & $\mathrm{II}(\mathrm{A})$ & 0.9123 & 0.6 & 22.60 & 29.42 & & \\
\hline & III & 0.9123 & 2 & 48.39 & 63.00 & & \\
\hline & total & 0.9123 & & 76.81 & 100.00 & & \\
\hline
\end{tabular}

ered in the study. In fact, what is important in this polymerization is the number of active sites that participate in the polymerization reaction. In absence of hydrogen, only $10.4 \%$ of total potential sites on the surface of the catalyst (as defined by the term $f_{\mathrm{H}_{2}}$ ) are activated during the polymerization according to the dormant site theory. However, in presence of hydrogen, namely $f_{\mathrm{H} 2}$, the percent of activated catalyst sites are dramatically increased, which can be seen from Fig. 7(A), where $x$ is the hydrogen molar ratio $\left(x=\mathrm{CH} / \mathrm{C}_{\mathrm{m}}\right)$ at the thermodynamic equilibrium condition that obeys the one from Sanchez and Lacombe equation (SLE) as its ruling equation of state $(E O S)^{16}$ and is calculated by Aspen software. The $f_{\mathrm{H} 2}$ amounts for each of the runs in this study are listed in Table 5, column 2.

Fig. 7(B) shows that the catalyst yield at $70{ }^{\circ} \mathrm{C}$ in the presence of different amounts of hydrogen is at maximum at $18 \mathrm{mg}$ of hydrogen. The reason for this behaviour could be explained according to the effect of hydrogen on $K_{d}$ of the catalyst, see Table 4 . The table implies that a hydrogen amount of $<18 \mathrm{mg}$ increases $f_{\mathrm{H} 2}$ amount, i.e., increases the percent of activated catalyst sites from the dormant sites. Then the existing activated catalyst sites react in the polymerization reaction. Accordingly, the catalyst yield is at maximum at $18 \mathrm{mg}$ of hydrogen (see Fig. 7(A) and Table 4). The excess of $18 \mathrm{mg}$ hydrogen reacts with freshly activated sites independently and leads to killing of the activated sites. Therefore, the number of activated sites for reacting with monomers are reduced, i.e., the reduction in the yield occurs according to Fig. 7(B). This behaviour is affirmed by referring to Fig. 8(A). The figure implies that an increase in hydrogen amount above $18 \mathrm{mg}$ not only causes an increase in the catalyst yield, but also reduces the useful life of the catalyst. As a result, increase in the hydrogen amount in order to raise the catalyst yield is not unlimited and should be controlled exactly. This model is useful for adjustment of the optimum amount, particularly in a commercial reactor.

Fig. 8(A) illustrates the cumulative catalyst yield during the polymerization time, i.e., two hours at the different hydrogen amounts and at $70{ }^{\circ} \mathrm{C}$ as the best temperature reaction. The figure shows that the performance of the developed model in presence of hydrogen is in accordance with experimental results, and concludes that the cumulative catalyst yield during the polymerization obeys that from the quadratic equation.

For the best operating condition in this study, i.e., Run 4 at $70{ }^{\circ} \mathrm{C}$ and $18 \mathrm{mg}$ of hydrogen, ${ }^{14}$ the variations of the $\mathrm{cu}-$ mulative catalyst yield during the polymerization time with its model are demonstrated in Fig. 8(B). 


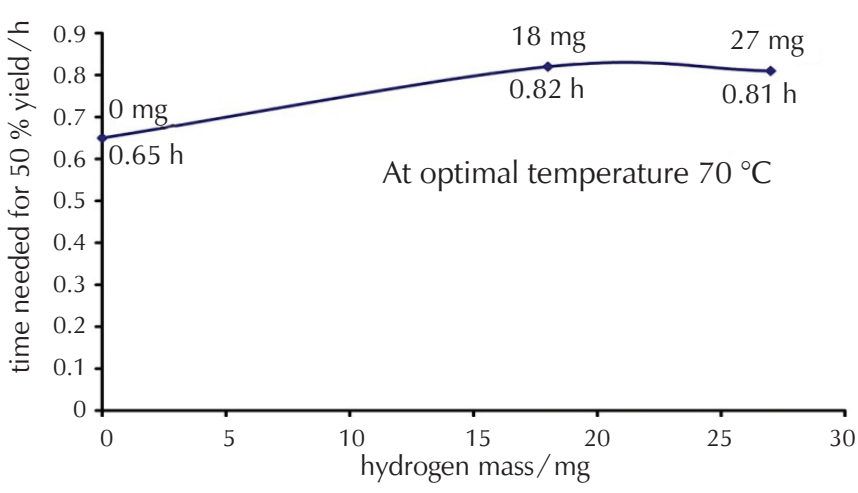

Fig. 9 - Variations of the time needed for $50 \%$ of the catalyst yield in presence of different hydrogen amounts at the best reaction temperature (Runs 2, 4, and 5)

The model shows that $0.82 \mathrm{~h}$ after beginning of the polymerization, $50 \%$ of the used catalyst yield is formed and after increase of the hydrogen amount $>18 \mathrm{mg}$ at the constant temperature, the needed time for catching $50 \%$ of the catalyst yield almost remains constant (Fig. 9). However, the catalyst yield is reduced, as shown in Fig. 7(B). The reason for this could be explained with the effect of the excess hydrogen amount of $18 \mathrm{mg}$ on $\mathrm{f}_{\mathrm{H} 2}$ and deactivation constant $\left(K_{\mathrm{d}}\right)$ of the catalyst as can be seen in Fig. $7(\mathrm{~A})$ and Table 4, respectively. The graphical image of $50 \%$ of the catalyst yield in the best operating conditions is shown in Fig. 10.

\section{Conclusion}

In this study, the authors attempted to propose a validated kinetic model, which would be able to reply to the existing gap. Therefore, two algorithms were outlined; first for the main program, and second for tuning and adjusting the constants of the kinetics equation based on the used Ziegler-Natta catalysts. By using the polymer moment balance approach (population balance), the coded program of the model was implemented in MATLAB ${ }^{\circledR}$ \& Simulink ${ }^{\circledR}$ software program. The model was validated by experimental data. The conclusions of this study are as follows:

1. This model was able to answer all research questions or the existing gaps appropriately. It means that the selected methodology (population balance approach) and proposed algorithms in this study were appropriate.

2. After investigation of the results, it can be concluded that temperature increase above $70{ }^{\circ} \mathrm{C}$, not only causes increase in catalyst yield, but also reduces the useful life of the catalyst, which is an undesired event.

3. Hydrogen amount increase above 18 mg not only causes increase in catalyst yield, but reduces the useful life of the catalyst.

4. In this study, five model equations have been proposed at different conditions to estimate the used catalyst yield via the polymerization time (Table 5).

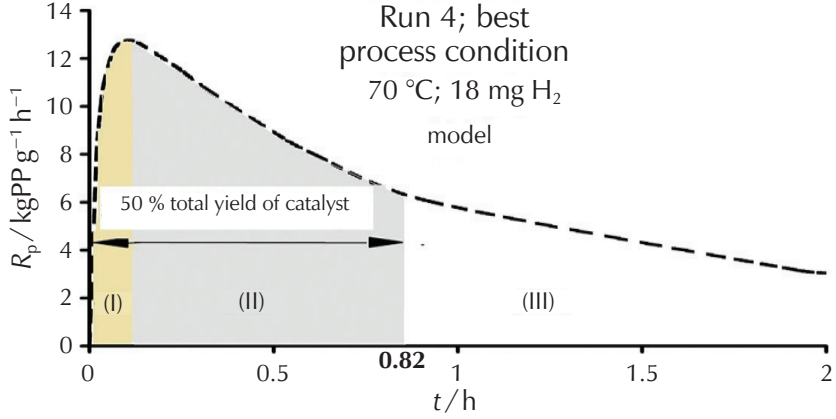

Fig. 10 - Graphical determination of the time needed for obtaining $50 \%$ of the catalyst yield by using the profile rate of the polymerization at the best operating conditions (Run 4)

It is suggested that other researchers should review recent results at different conditions using different types of catalyst.

\section{List of abbreviations and symbols}

C - total active site concentration, $\mathrm{mol} \mathrm{dm}^{-3}$

$C_{\mathrm{d}}$ - dead-site concentration, $\mathrm{mol} \mathrm{dm}^{-3}$

$c_{j} \quad$ - component $j$ bulk concentration, $\mathrm{mol} \mathrm{dm}^{-3}$

$C_{j, R} \quad$ - concentration into the reactor, $\mathrm{mol} \mathrm{dm}^{-3}$

$c_{\mathrm{k}} \quad$ - type $k$ active specie concentration, $\mathrm{mol} \mathrm{dm}^{-3}$

$C_{\mathrm{p}} \quad$ - potential site concentration, $\mathrm{mol} \mathrm{dm^{-3 }}$

$D_{k n}$ - dead polymer chain concentration with $n$ monomers originated from site $k, \mathrm{~mol} \mathrm{dm}^{-3}$

$Ð$ - dispersity

$M_{\mathrm{w}}$ - mass average molecular weight, $\mathrm{kg} \mathrm{mol}^{-1}$

$N_{C}$ - number of liquid-phase components

$n_{j, R}-$ moles of component $j$ into reactor

$n_{j, \mathrm{a}}-$ moles of $j$ sorbed in the amorphous polymer phase

$n_{j, 1}-$ moles of $j$ in the liquid phase

$N_{\mathrm{m}}$ - number of monomers

$N_{\mathrm{s}}$ - number of sites

$O_{r k}$ - order of reaction $r$ for site $k$

$P_{n, i k}$ - growing polymer chain with $n$ monomers with end-group $i$ from site $k, \mathrm{~mol} \mathrm{dm}^{-3}$

$P_{0 k}$ - vacant site $k$ concentration, $\mathrm{mol} \mathrm{dm}^{-3}$

$R_{\mathrm{p}} \quad$ - polymerization rate, $\mathrm{kgg}(\mathrm{cat})^{-1} \mathrm{~h}^{-1}$

$R_{\mathrm{p} 0} \quad$ - initial polymerization rate, $\left.\mathrm{kgg}_{\mathrm{g}} \mathrm{cat}\right)^{-1} \mathrm{~h}^{-1}$

$t \quad$ - time, $\mathrm{s}$

$T_{\mathrm{r}} \quad$ - reactor temperature, $\mathrm{K}$

$T_{\mathrm{f}} \quad$ - feed stream temperature, $\mathrm{K}$

$V_{R} \quad$ - reactor volume, $\mathrm{m}^{3}$

$Y \quad$ - yield, g PP

$R_{r k, n}-r$ reaction from site $k$ for a growing chain with $n$ monomers, $\mathrm{mol} \mathrm{m}^{-3} \mathrm{~s}^{-1}$

$R_{j} \quad-j$ component reaction rate, $\mathrm{mol} \mathrm{m}^{-3} \mathrm{~s}^{-1}$ 


\section{References}

1. R. Mülhaupt, Catalytic polymerization and post polymerization catalysis fifty years after the discovery of Ziegler's catalysts, Macromol. Chem. Phys. 204 (2003) 289, doi: https:// doi.org/10.1002/macp.200290085.

2. S. Reginato, J. J. Zacca, A. R. Secchi, Modeling and simulation of propylene polymerization in nonideal loop reactors, AIChE Journal 49 (2003) 2642, doi: https://doi.org/10.1002/ aic.690491017.

3. G. H. Varshouee, A. Heydarinasab, A. Vaziri, B. Roozbahani, Hydrogen Effect Modeling on Ziegler-Natta Catalyst and Final Product Properties in Propylene Polymerization, Bull. Chem. Soc. Ethiop. 32 (2018) 371-386, doi: https://doi. org/10.4314/bcse.v32i2.15.

4. V. Busico, R. Cipullo, A. Mingione, L. Rongo, Accelerating the Research Approach to Ziegler-Natta Catalysts, Ind. Eng. Chem. Res. 55 (2016) 2686, doi: https://doi.org/10.1021/ acs.iecr.6b0009.

5. J. T. Pater, G. Weickert, W. P. van Swaaij, Polymerization of liquid propylene with a $4^{\text {th }}$ generation Ziegler-Natta catalyst-influence of temperature, hydrogen and monomer concentration and prepolymerization method on polymerization kinetics, Chem. Eng. Sci. 57 (2002) 3461, doi: https:// doi.org/10.1016/S0009-2509(02)00213-0.

6. F. Shimizu, J. Pater, W. P. Van Swaaij, G. Weickert, Kinetic study of a highly active $\mathrm{MgCl}_{2}$-supported Ziegler-Natta catalyst in liquid pool propylene polymerization. II. The influence of alkyl aluminum and alkoxysilane on catalyst activation and deactivation, J. Appl. Polym. Sci. 83 (2002) 2669, doi: https://doi.org/10.1002/app.10236.

7. G. Guastalla, U. Giannini, The influence of hydrogen on the polymerization of propylene and ethylene with an $\mathrm{MgCl}_{2}$ supported catalyst, Macromol. Rapid Commun. 4 (1983) 519, doi: https://doi.org/10.1002/marc.1983.030040803.

8. R. Spitz, P. Masson, C. Bobichon, A. Guyot, Activation of propene polymerization by hydrogen for improved $\mathrm{MgCl}_{2}$-supported Ziegler-Natta catalysts, Macromol. Chem. Phys. 190 (1989) 717, doi: https://doi.org/10.1002/ macp.1989.021900405.

9. L. A. Rishina, E. I. Vizen, L. N. Sosnovskaja, F. S. Dyachkovsky, Study of the effect of hydrogen in propylene polymerization with the $\mathrm{MgCl}_{2}$-supported Ziegler-Natta catalyst - part 1. Kinetics of polymerization, Europ. Polym. J. 30 (1994) 1309, doi: https://doi.org/10.1016/0014-3057(94)90143-0.

10. K. Soga, T. Siono, Effect of hydrogen on the molecular weight of polypropylene with Ziegler-Natta catalysts, Polym. Bullet. 8 (1982) 261, doi: https://doi.org/10.1007/BF00700287.

11. R. Kahraman, M. Erdogan, T. Bilgic, Polymerization of propylene using a prepolymerized high-active ZieglerNatta catalyst. I. Kinetic studies, J. Appl. Polym. Sci. 60 (1996) 333, doi: https://doi.org/10.1002/(SICI)10974628(19960418)60:3<333::AID-APP6 > 3.0.CO;2-M.
12. M. Ali, B. Betlem, B. Roffel, G. Weickert, Hydrogen response in liquid propylene polymerization: Towards a generalized model, AIChE Journal 52 (2006) 1866, doi: https://doi. org/10.1002/aic.10783.

13. G. H. Varshouee, A. Heydarinasab, A. Vaziri, B. Roozbahani, Determining Final Product Properties and Kinetics Studies of Polypropylene Polymerization by a Validated Mathematical Model, Bull. Chem. Soc. Ethiop. 32 (2018) 579, doi: https:// doi.org/10.4314/bcse.v32i3.16.

14. G. H. Varshouee, A. Heydarinasab, A. Vaziri, S. M. G. Zarand, Determining the Best Reaction Temperature and Hydrogen Amount for Propylene Polymerization by a Mathematical Model, Kem. Ind. 68 (3-4) (2019) 119-127, doi: https://doi. org/10.15255/KUI.2018.038.

15. G. H. Varshouee, A. Heydarinasab, A. Vaziri, B. Roozbahani, A mathematical model for determining the best process conditions for average Molecular weight and melt flow index of polypropylene, Bull. Chem. Soc. Ethiop. 33 (2019) 169, doi: https://doi.org/10.4314/bcse.v33il.17.

16. G. M. N. Costa, S. Kislansky, L. C. Oliveira, F. L. P. Pessoa, S. A. B. Vieira de Melo, M. Embiruçu, Modeling of solid-liquid equilibria for polyethylene and polypropylene solutions with equations of state, J. Appl. Polym. Sci. 121 (2011) 1832, doi: https://doi.org/10.1002/app.33128.

17. Y. P. Zhu, Z. H. Luo, J. Xiao, Multi-scale product property model of polypropylene produced in a FBR: From chemical process engineering to product engineering, Comput. Chem.Eng. 71 (2014) 39, doi: https://doi.org/10.1016/j. compchemeng.2014.07.013.

18. H. G.Yuan, T. W Taylor. K. Y. Choi, W. H. Ray, Polymerization of Olefins through Heterogeneous Catalysis. 1. Low-Pressure Propylene Polymerization in Slurry with Ziegler-Hatta Catalyst, J. Appl. Polym. Sci. 27 (1982) 1691, doi: https://doi. org/10.1002/app.1982.070270526.

19. J. B. P.Soares, A. Hamielec, Kinetics of Propylene Polymerization with A Non-Supported Heterogeneous Ziegler-Natta Catalyst-Effect of Hydrogen on Rate of Polymerization, Stereoregularity, and Molecular Weight Distribution, Polymer 37 (1996) 4607, doi: https://doi.org/10.1016/00323861(96)00286-8.

20. J. J. C. Samson, J. B. Bosman, G. Weickert, K. R. Westerterp, Liquid-phase polymerization of propylene with a highly active Ziegler-Natta catalyst. Influence of hydrogen, cocatalyst, and electron donor on reaction kinetics, J. Polym. Sci. Part A: Polym. Chem. 37 (1999) 219, doi: https://doi.org/10.1002/ (SICI)1099-0518(19990115)37:2<219::AID-POLA12>3.0. $\mathrm{CO} ; 2-3$.

21. S. Floyd, T. Heiskanen, T. W. Taylor, G. E. Mann, W. H. Ray, Polymerization of olefins through heterogeneous catalysis. VI. Effect of particle heat and mass transfer on polymerization behavior and polymer properties, J. Appl. Polym. Sci. 33 (1987) 1021, doi: https://doi.org/10.1002/app.1987.070330402. 


\section{SAŽETAK}

\section{Matematički model za ispitivanje utjecaja temperature reakcije i količine vodika na iskorištenje katalizatora tijekom polimerizacije propilena \\ Gholam Hossain Varshouee, ${ }^{a *}$ Amir Heydarinasab, ${ }^{a}$ Ali Vaziri, ${ }^{a}$ and Seyed Mehdi Ghafelebashi Zarand ${ }^{b}$}

U ovom radu ispitan je učinak temperature reakcije i količine vodika, kao najučinkovitijih procesnih varijabli na iskorištenje Ziegler-Nattinog katalizatora tijekom polimerizacije propilena pomoću validiranog matematičkog modela. Pristup koji je primijenjen u ovom modeliranju bila je tehnika ravnoteže polimernih momenata (pristup populacijske ravnoteže) izvedena iz očekivane statističke vrijednosti. Model je kodiran u programima MATLAB ${ }^{\circledR}$ i Simulink ${ }^{\circledR}$, a zatim potvrđen eksperimentalnim podatcima iz laboratorijskog reaktora. Glavni cilj ovog istraživanja bio je dobiti uvid u učinkovitost Ziegler-Nattinog katalizatora u odnosu na promjenu varijabli. Model bi mogao biti primjenjiv proizvođačima katalizatora kod procjene i poboljšanja njihovih katalizatora, a također bi mogao biti koristan procesnim kemijskim inženjerima za lakše upravljanje postrojenjem, zamjenu novog katalizatora, optimiziranje procesnih uvjeta i iskorištenje maksimalnog katalitičkog potencijala. Sukladno tome, model bi se mogao primijeniti u temeljnim i primijenjenim istraživanjima u ovom području.

\section{Ključne riječi}

Iskorištenje katalizatora, Ziegler-Nattini katalizatori, temperatura reakcije, vodik, modeliranje, populacijska ravnoteža

a Department of Petroleum and Chemical Engineering, Science and Research Branch, Islamic Azad University, Tehran, Iran

b Polymer Group, Research and Technology, National Petrochemical Company, Tehran, Iran
Izvorni znanstveni rad Prispjelo 24. prosinca 2018. Prihvaćeno 10. travnja 2019. 